\title{
An Analysis of Hazards Caused by Emissions of Amines from Carbon Dioxide Capture Installations
}

\author{
Andrzej Rusin*, Katarzyna Stolecka \\ Silesian University of Technology, Institute of Power Engineering and Turbomachinery, \\ Konarskiego 18, 44-100 Gliwice, Poland
}

Received: 29 December 2015

Accepted: 1 February 2016

\begin{abstract}
Amine-based post combustion carbon dioxide is one leading technology for coal-fired power plants. Monoethanolamine is commonly used in carbon dioxide absorption due to its many advantages such as high reactivity, high carbon dioxide cyclic capacity, and low cost. Solvent degradation is a major problem during the $\mathrm{CO}_{2}$ absorption process because in sunlight amines undergo reactions with atmospheric oxidation (photo-oxidation) to form compounds such as nitrosamines, nitramines, and amides. They are toxic and carcinogenic for humans at very low levels. This paper identifies safety limits of amine emissions and determines hazardous concentration zones.
\end{abstract}

Keywords: amine absorption, carbon dioxide capture, amine emissions, hazardous zone

\section{Introduction}

The requirements of the European Union concerning the obligation to reduce greenhouse gas emissions and electricity consumption on the one hand, and an increase in the share of renewable sources on the other, force its member states, including Poland, to take actions in the field of nuclear power engineering, use alternative fuels (such as hydrogen), or develop technologies of $\mathrm{CO}_{2}$ capture, storage, and industrial utilization. These measures, referred to as CCS methods, are based on carbon dioxide separation during the combustion of fossil fuels, suitable $\mathrm{CO}_{2}$ preparation for transport, and gas storage in appropriate sites, as well as its use as a raw material in other processes. The EU requires that newly designed and cur-

*e-mail: andrzej.rusin@polsl.pl rently built power units should be adapted for using CCS technologies. At present, three basic and technologically mature methods of carbon dioxide capture may be distinguished: post-combustion, pre-combustion, and oxy-combustion.

In the post-combustion capture method, carbon dioxide is separated from the flue gas mass flow. This installation type may be used in already existing power plants, and the processes that take place here concern absorption and adsorption, as well as membrane and cryogenic separation.

The carbon dioxide pre-combustion capture method comprises processes of fuel decarbonization. Carbon dioxide separation consists of separating carbon from a gaseous fuel before the proper combustion process starts. The processes that change carbon compounds into gaseous fuels include steam reforming of gaseous and oil fuels and coal gasification. 
Oxy-combustion results in a higher content of carbon dioxide in flue gases. Additionally, it involves a reduction in the flue gas mass flow. However, the problem here is the rise in the flue gas temperature and the need to build an oxygen-production installation.

All the methods mentioned above may make use of absorption as well as cryogenic, membrane, or acoustic separation [1-3]

\section{Absorption}

Carbon dioxide capture by means of post-combustion amine-based absorption is one of the most technologically developed methods used to reduce gas emissions, especially in power plants fired with fossil fuels. The aminebased scrubbing is a proven method available on the market and very effective in terms of carbon dioxide separation. Absorption is based on the process of a gas being absorbed by a liquid in which the gas gets dissolved. The process flowchart is presented in Fig. 1. The basic element of an amine-based installation intended for carbon dioxide capture is an absorber. The flue gas flow directed into it comes into contact with an aqueous solution of amine and, as a result, carbon dioxide is captured. Then the $\mathrm{CO}_{2}$-saturated solution of amine is directed to a desorber through a regenerative heat recovery node. In the desorber column, the carbon dioxide captured in the absorber is separated and the solution is regenerated. Due to the effect of heat supplied to the desorber, the amine- $\mathrm{CO}_{2}$ bonds are broken and the gaseous carbon dioxide is desorbed from the solution. The hot vapours floating in the desorber give up heat to the counter-current solution flow and their partial condensation occurs. The water vapour-carbon dioxide mixture collected from the top is cooled and the condensate is returned to the system [4].
Typically, the following solutions of amines are used as solvents in the chemical absorption processes: monoethanolamine (MEA) and diethanolamine (DEA), as well as the aqueous solution of ammonia or acid potassium carbonate. An example of a working CCS system based on the absorption process is the test unit in the Technology Centre Mongstad (Norway) [5]. The $\mathrm{CO}_{2}$ capture technologies applied in it and based on the use of amines and cooled ammonia are tested on a wide scale. It is anticipated that 100,000 tons of $\mathrm{CO}_{2}$ per year will be removed in this demonstration plant. A full-scale installation that should make it possible to capture about $1 \mathrm{Mt}$ of carbon dioxide per year is planned after the testing phase.

In the Polish power sector, a pilot installation was built within the completion of the Strategic Programme "Advanced technologies for obtaining energy," Task 1 - Development of technologies for highly efficient zero-emission coal-fired power units integrated with $\mathrm{CO}_{2}$ capture from flue gases. The installation was used to separate flue gases in the Laziska and the Jaworzno III power plants. In over 100 tests more than 20 tons of $\mathrm{CO}_{2}$ were captured, with $\mathrm{CO}_{2}$ separation efficiency exceeding $90 \%$.

\section{Monoethanolamine}

Due to its numerous advantages such as high reactivity, stability, regeneration opportunity, and low cost, monoethanolamine (MEA) is used in carbon dioxide capture processes. Monoethanolamine (ethanolamine, 2-aminoethanol) is a colourless or light-yellow liquid characterized by a specific fishy- or ammonia-like smell and hygroscopicity. Apart from being used in carbon dioxide capture processes it is known for its application in pharmaceuticals, cosmetics, and household chemistry products. MEA is obtained due to the reaction of ethylene oxide with am-

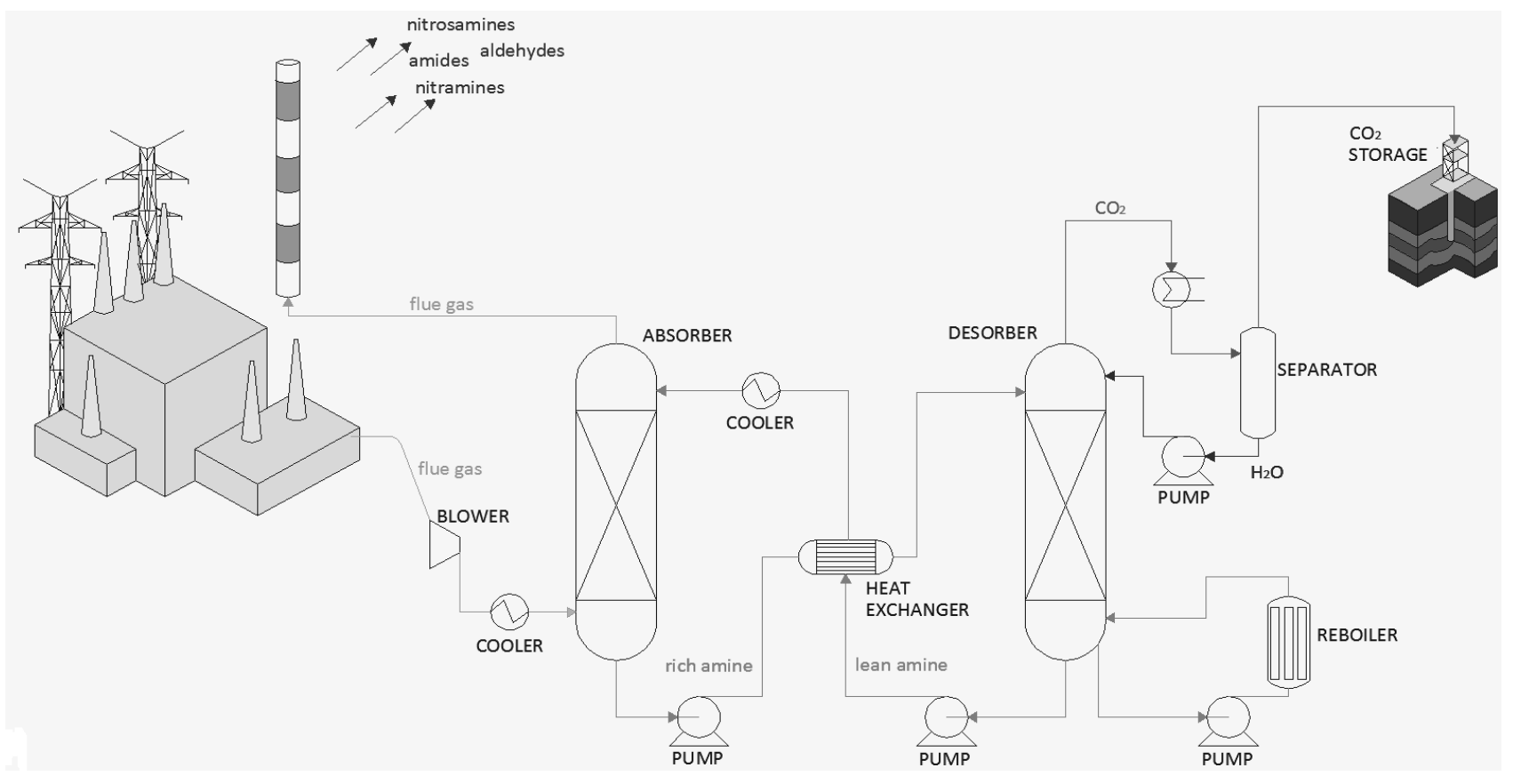

Fig. 1. Amine-based installation intended for carbon dioxide capture. 
Table 1. Monoethanolamine basic properties.

\begin{tabular}{|c|c|}
\hline molecular formula & $\mathrm{C}_{2} \mathrm{H}_{7} \mathrm{NO}$ \\
\hline molecular mass & $61.08 \mathrm{~g} / \mathrm{mol}$ \\
\hline self-ignition temperature & $410^{\circ} \mathrm{C}$ \\
\hline boiling point & $170.8^{\circ} \mathrm{C}$ \\
\hline $\mathrm{pH}$ & 12.1 \\
\hline density: at $25^{\circ} \mathrm{C}$ & $1.0117 \mathrm{~g} / \mathrm{cm}^{3}$ \\
\hline melting point & $10.3^{\circ} \mathrm{C}$ \\
\hline
\end{tabular}

Table 2. Diethanolamine basic properties.

\begin{tabular}{|c|c|}
\hline molecular formula & $\mathrm{C}_{4} \mathrm{H}_{11} \mathrm{NO}_{2}$ \\
\hline molecular mass & $105.14 \mathrm{~g} / \mathrm{mol}$ \\
\hline self-ignition temperature & $370^{\circ} \mathrm{C}$ \\
\hline boiling point & $270^{\circ} \mathrm{C}$ \\
\hline density: at $20^{\circ} \mathrm{C}$ & $1.09 \mathrm{~g} / \mathrm{ml}$ \\
\hline melting point & $27^{\circ} \mathrm{C}$ \\
\hline
\end{tabular}

monia or formaldehyde with nitromethane. Its aqueous solution behaves like a weak base that can neutralize carbon dioxide. It is flammable and toxic and has a harmful effect if inhaled. It causes irritation to the respiratory system, skin, and eyes. Long exposure to MEA may cause nausea, vomiting, exhaustion, headaches, and fainting. Monoethanolamine is classed as a hazardous product: $\mathrm{Xn}$ is a harmful product causing irritation while $\mathrm{C}$ is a corrosive product causing burns. Basic characteristics of this amine are listed in Table $1[6,7]$.

Another solvent used in carbon dioxide capture installations is diethanolamine (DEA), a transparent colourless liquid with an ammonia-like smell. Diethanolamine is a toxic substance obtained from ethanolamine and the third equivalent of ethylene oxide. It is used as an anticorrosive agent and in the production of medicines, cosmetics, and paints. Diethanolamine has a harmful effect if inhaled or swallowed, or if it comes in contact with the skin. Basic characteristics of this amine are listed in Table $2[7,8]$.

\section{Hazards Posed by Amine-Based Methods}

Since the beginning of the $21^{\text {st }}$ century intensive research has been pursued on post-combustion methods of carbon dioxide capture, focusing on new solvents with very high reactivity, low regeneration costs, high absorptivity, and thermal stability. $\mathrm{CO}_{2}$ capture processes have already been optimized to a great extent to achieve possibly low costs and low energy consumption. However, degradation of the solvents (amines) used in the absorption process remains an essential problem because it leads to the formation of hazardous compounds such as ammonia, aldehydes, amides, alkyl amines, and nitrosamines, etc. Therefore, the development of this particular technology of carbon dioxide capture requires a precise identification of potential hazards posed by emissions of the compounds mentioned above. The carcinogenic effect of the substances has already been identified as a health hazard, whereas the level of the hazard related to the use of MEA in $\mathrm{CO}_{2}$ capture processes is still unknown [7-9].

In the presence of light, amines released in the liquid or gaseous form react with atmospheric oxidants including oxidized nitrogen compounds (photo-oxidation). As a result, new compounds are formed such as nitrosamines, nitramines, and amides. The formation of nitrosamines is especially dangerous because these substances are toxic and carcinogenic even at very low concentrations. Recent studies indicate that atmospheric photo-oxidation of amines may produce concentrations of compounds that are hazardous both to humans and to the environment. Post-combustion amine emissions from the $\mathrm{CO}_{2}$ capture installation differ depending on the operating conditions, the amine type, and whether or not a water wash unit is used. Monoethanolamine is the most comprehensively analysed solvent used for carbon dioxide separation from flue gases. It is subject to oxidation and thermal degradation in the carbon dioxide capture installation [7-9]. Using MEA as a scrubbing sorbent in the carbon dioxide capture process may involve MEA emissions of $0.1-0.8 \mathrm{~kg}$ per ton of $\mathrm{CO}_{2}$ captured in an installation without a water wash unit. The emissions may be lower, i.e., 0.01-0.03 kg per ton of $\mathrm{CO}_{2}$ if a water wash unit is applied. A typical carbon dioxide capture installation captures $1 \mathrm{Mt}$ of carbon dioxide per year and emits 1-4 ppmv MEA in flue gases, which is equal to 40-160 t/year. [10] give MEA emissions at the level of $80 \mathrm{t} /$ year for a $420 \mathrm{MW}$ power unit fired with natural gas, with a water wash unit.

\section{Hazardous Concentration Level}

Hazardous concentrations of substances are defined as the upper limit of concentrations in air that does not cause harmful effects to humans or ecosystems. Establishing safe concentration levels, the most perceptible unfavourable effect caused by a given group of compounds in any area of the target environment (drinking water, vegetation, terrestrial fauna, ecosystem types) and in the receptor organisms (algae, invertebrates, fish, humans) should be taken into account. The negative effects of the impact of the substances mentioned above may have an immediate character (after a few hours) or a long-term one (after a few weeks, months, years) depending on the receptor organism (a few days for algae, several years for humans). Safe concentrations in relation to human health may be established based on literature data about toxicokinetics/ metabolism and experimental toxicology.

The human organism absorbs MEA through inhalation and oral and/or cutaneous absorption. Information can be found in reference literature [8-10] about the effects of the MEA impact, such as the occupational asthma, skin allergies, and reproductive as well as developmental toxicity. However, there are no detailed studies on monoethanolamine carcinogenicity. [11] suggest that the 
Table 3. Permissible concentrations of compounds.

\begin{tabular}{|c|c|c|c|}
\hline Compound & Exposure & Toxicity & Safety limits (time) \\
\hline \multirow[t]{2}{*}{ MEA } & inhalation & human health, subchronic & $\begin{array}{c}10 \mu \mathrm{g} / \mathrm{m}^{3} \\
\text { (monthly average) }\end{array}$ \\
\hline & aqueous environment & algae/bacteria, chronic & $7,500 \mathrm{ng} / \mathrm{l}$ \\
\hline \multirow{2}{*}{ DEA } & inhalation & human health, acute & $\begin{array}{c}75 \mathrm{mg} / \mathrm{m}^{3} \\
\text { (8-hour average) }\end{array}$ \\
\hline & aqueous environment & algae/bacteria, chronic & $200,000 \mathrm{ng} / 1$ \\
\hline \multirow{4}{*}{ nitrosamines } & inhalation & human health, carcinogenic & $\begin{array}{c}10 \mu \mathrm{g} / \mathrm{m}^{3} \\
\text { (8-hour average) }\end{array}$ \\
\hline & inhalation & human health, carcinogenic & $\begin{array}{c}0.02 \mathrm{ng} / \mathrm{m}^{3} \\
\text { (monthly average) }\end{array}$ \\
\hline & drinking water & human health, carcinogenic & $7 \mathrm{ng} / \mathrm{l}$ \\
\hline & aqueous environment & algae/bacteria, chronic & $25 \mathrm{ng} / 1$ \\
\hline \multirow{2}{*}{ nitramines } & drinking water & human health, carcinogenic & $1 \mu \mathrm{g} / 1$ \\
\hline & aqueous environment & fish, chronic & $200 \mathrm{ng} / 1$ \\
\hline formamide & aqueous environment & invertebrates & $24,000 \mathrm{ng} / \mathrm{l}$ \\
\hline acetamide & inhalation & human health, carcinogenic & $\begin{array}{c}0.05 \mu \mathrm{g} / \mathrm{m}^{3} \\
\text { (monthly average) }\end{array}$ \\
\hline
\end{tabular}

population should not be exposed to MEA concentrations higher than $10 \mu \mathrm{g} / \mathrm{m}^{3}$, and this value may be adopted as the average monthly permissible safe level of monoethanolamine in air. The standards enforced in Norway in 2011 specify monoethanolamine occupational exposure at the level of $2.5 \mathrm{mg} / \mathrm{m}^{3}$ [8].

In the case of the other amine used in CCS technologies, DEA, no data concerning permissible long-term concentrations are available. The short-term permissible exposure level (PEL) laid out by the Occupational Safety and Health Administration (OSHA) in the USA is 25 ppmv, which corresponds to $75 \mathrm{mg} / \mathrm{m}^{3}$ as an eight-hour average value.

The compounds formed due to amine degradation are, for example, nitrosamines, formamide, and acetamide. Formamide poses a health hazard to humans. It may cause cancer and affects reproductive functions. However, the 90-day tests do not provide a sufficient body of evidence to define the effects resulting from inhaling it. On the other hand, some test results point to cases of the liver tumours in animals exposed to oral consumption of acetamide. The standards enforced in Norway in 2011 specify the permissible concentration of formamide and acetamide at the level of 18 and $45 \mathrm{mg} / \mathrm{m}^{3}$, respectively. The California Environment Protection Agency regulations stipulate the permissible level of acetamide concentration (if inhaled) at $0.05 \mu \mathrm{g} / \mathrm{m}^{3}$ [8].

Although the cause-and-effect relationship has not been defined decisively, there is enough evidence that, like formamide, nitrosamines should be considered compounds causing cancer in humans. In Germany, the occupational exposure of their concentration should not

Table 4. Parameters of selected power plants [7].

\begin{tabular}{|c|c|c|c|c|c|c|c|c|}
\hline & \multirow{2}{*}{$\begin{array}{l}\text { Capcity, } \mathrm{t} \text { of } \\
\mathrm{CO}_{2} / \text { year }\end{array}$} & \multicolumn{2}{|c|}{ Absorber } & \multirow{2}{*}{$\begin{array}{c}\text { Volumetric } \\
\text { flow rate } \\
\mathrm{Nm}^{3} / \mathrm{h}\end{array}$} & \multirow{2}{*}{$\begin{array}{c}\text { Flue gas } \\
\text { flow rate } \\
\mathrm{m} / \mathrm{s}\end{array}$} & \multirow{2}{*}{$\begin{array}{c}\text { Efficiency } \\
\text { of recovery } \\
\%\end{array}$} & \multicolumn{2}{|c|}{$\begin{array}{l}\text { Emissions rate } \\
\mathrm{g} / \mathrm{s}\end{array}$} \\
\hline & & $\mathbf{h}, \mathbf{m}$ & $\mathbf{d}, \mathbf{m}$ & & & & NDMA & NDEA \\
\hline $\begin{array}{l}\text { International Test Centre for } \\
\qquad \mathrm{CO}_{2} \text { Capture }\end{array}$ & 365 & 10 & 0.3 & 155 & 0.70 & 70 & $1.15 \mathrm{E}-05$ & $8.38 \mathrm{E}-06$ \\
\hline $\begin{array}{l}\text { Geo Bei-dian in Beijing, } \\
\text { China }\end{array}$ & 3,000 & 30 & 1.2 & 1,273 & 0.36 & 70 & $9.47 \mathrm{E}-05$ & $6.89 \mathrm{E}-05$ \\
\hline $\begin{array}{c}\text { Shengli Power Plant in } \\
\text { Dongying, China }\end{array}$ & 40,000 & 38.5 & 3 & 16,970 & 0.77 & 70 & $1.26 \mathrm{E}-03$ & $9.18 \mathrm{E}-04$ \\
\hline $\begin{array}{c}\text { Searles Valley } \\
\text { Minerals } \mathrm{CO}_{2} \text { capture plant }\end{array}$ & 146,000 & 36.3 & 4.4 & 61,941 & 1.30 & 70 & 4.61E-03 & $3.35 \mathrm{E}-03$ \\
\hline $\begin{array}{c}\text { Boundary Darn carbon } \\
\text { dioxide capture plant }\end{array}$ & $1,000,000$ & 54.9 & 10.7 & 424,250 & 1.51 & 70 & $3.16 \mathrm{E}-02$ & $2.30 \mathrm{E}-02$ \\
\hline
\end{tabular}


exceed the eight-hour average of $10 \mu \mathrm{g} / \mathrm{m}^{3}$ [8]. In the case of nitramines, there are just a few studies on their impact on human health. The mutagenic and carcinogenic effect of nitramines seems to be generally smaller compared to nitrosamines. However, based on the available data it is impossible to determine the permissible concentration in the case of human exposure due to inhalation. The safety limits for substances and compounds that might be formed as a result of amine oxidation are presented in Table 3 [8].

Table 4 lists example values of emissions of nitrosamines in the form of NDMA and NDEA for five power plants with an absorption-based carbon dioxide capture installation given by [7]. The capture capacity of individual installations is at the level of $365,1,460,3000,146,000$, and 1 million tons of carbon dioxide per year, respectively.

\section{Estimation of the Concentrations of Compounds Formed in the Amine-Based Process of Carbon Dioxide Capture}

\section{Range of Zones with a Higher Concentration of MEA}

The adopted scenario of calculations takes account of a $900 \mathrm{MW}$ supercritical power unit, which may be a typical power engineering facility currently built in Poland. The unit is equipped with an absorption-based carbon dioxide capture installation with $\mathrm{CO}_{2}$ capture efficiency of $90 \%$. The flue gas mass flow totals $686.6 \mathrm{~kg} / \mathrm{s}$, and according to the calculation results provided by [2] it is assumed that the MEA mass flow released with flue gases is $2.7 \cdot 10^{-3} \mathrm{~kg} / \mathrm{s}$. Fig. 2 presents the range of a cloud with the MEA concentration equal to or higher than $2.5 \mathrm{mg} / \mathrm{m}^{3}$, assuming wind speed of $1 \mathrm{~m} / \mathrm{s}$ and atmospheric stability D, which means neutral weather conditions of slightly windy and sunny.

The impact of an increase in the wind speed on the range of a cloud with the MEA concentration higher than 2.5 and higher than $1 \mathrm{mg} / \mathrm{m}^{3}$ is presented in Fig. 3. In the

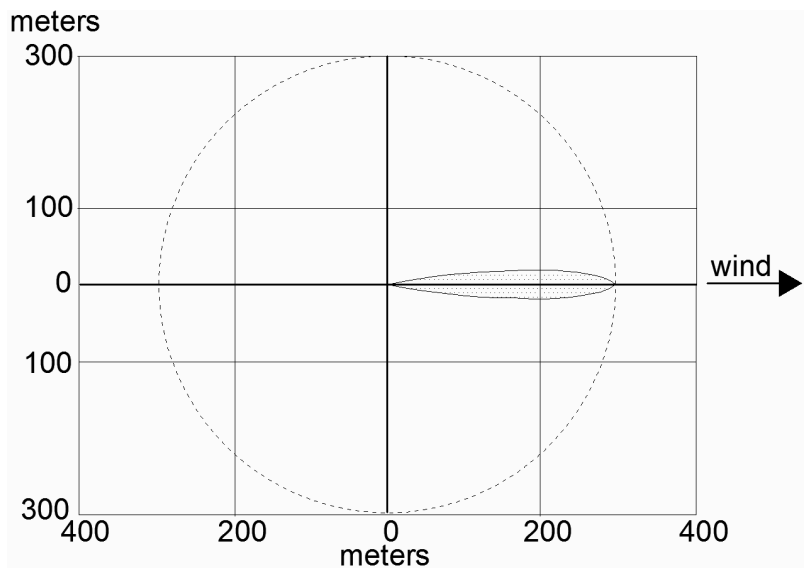

Fig. 2. Range of a monoethanolamine cloud with a concentration equal to or higher than $2.5 \mathrm{mg} / \mathrm{m}^{3}$ (wind speed: $1 \mathrm{~m} / \mathrm{s}$ ).

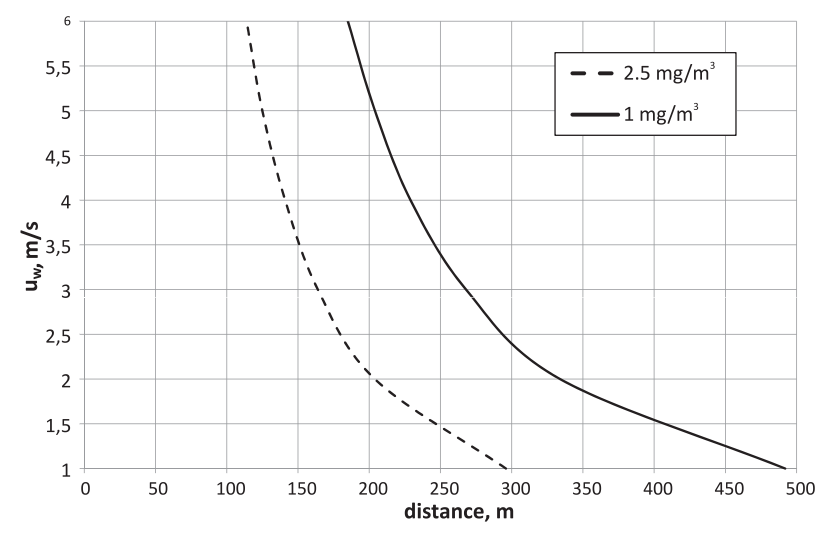

Fig. 3. Range of the zone with monoethanolamine concentration higher than 2.5 and higher than $1 \mathrm{mg} / \mathrm{m}^{3}$, depending on wind speed.

calculations performed using ALOHA v5.4.4. software [12], for every wind speed value the same atmospheric stability category is assumed to be D.

Analysing the charts presented above, it can be noticed that the monoethanolamine cloud with the concentration of $2.5 \mathrm{mg} / \mathrm{m}^{3}$ will reach the range of about $300 \mathrm{~m}$ in the case of a lower wind speed value and about $114 \mathrm{~m}$ if the wind speed is $6 \mathrm{~m} / \mathrm{s}$, which means that a faster wind disperses the cloud, reducing the concentration of harmful substances.

The concentration of the MEA cloud released with flue gases will vary according to the distance from the emission source. Fig. 4 presents changes in the monoethanolamine concentration depending on the distance from the emission source for different wind speed values, i.e., 1, 3, $6 \mathrm{~m} / \mathrm{s}$.

Analysing the chart, it can be seen that at a distance of about $200 \mathrm{~m}$ from the emission source the MEA concentration will change in the range from about 0.97 to $5.15 \mathrm{mg} / \mathrm{m}^{3}$, depending on the wind speed. The monoethanolamine concentration will decrease with a rise in the distance from the emission source and will fall below $1 \mathrm{mg} / \mathrm{m}^{3}$ at a distance of $500 \mathrm{~m}$, regardless of wind speed.

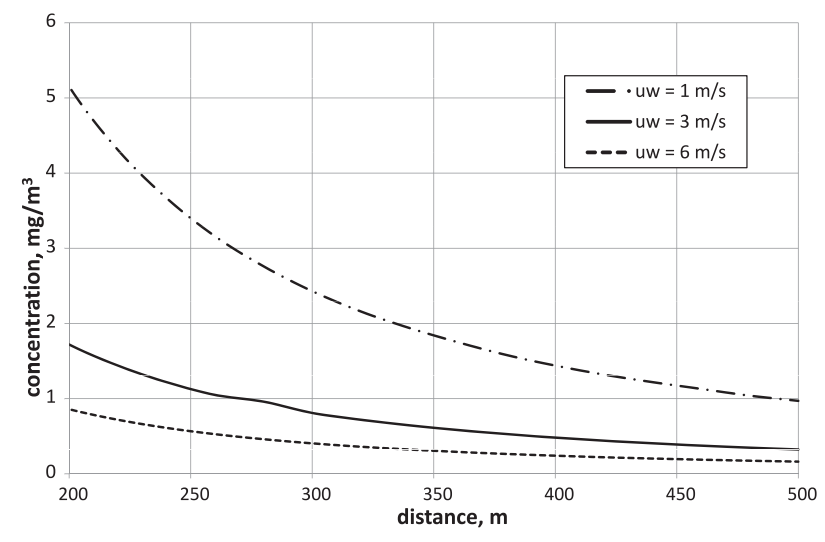

Fig. 4. Monoethanolamine concentration depending on the distance from the release source. 


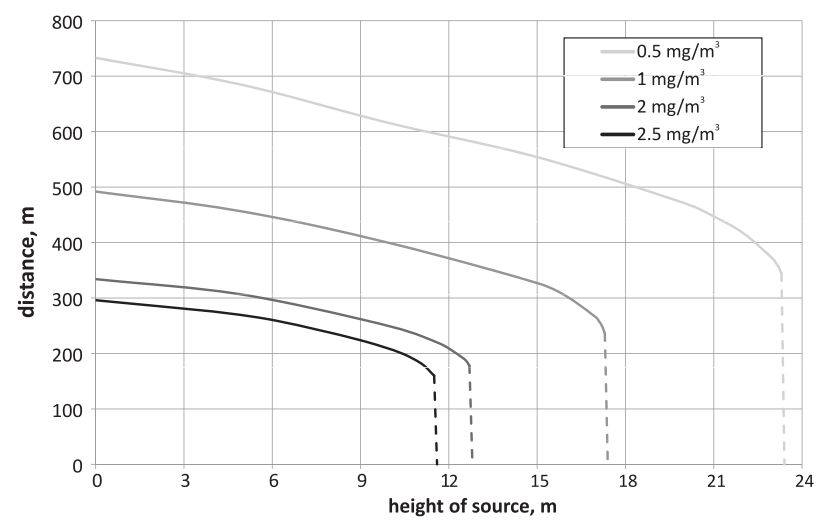

Fig. 5. MEA cloud zone range depending on emission source height.

The range of a cloud with a given concentration of monoethanolamine is also affected by the emission source height (i.e., the height of the stack). The dependence is shown in Fig. 5, assuming the wind speed of $1 \mathrm{~m} / \mathrm{s}$ and atmospheric stability D. The curves presented in the chart relate to different levels of the MEA concentration of 0.5 , 1,2 , and $2.5 \mathrm{mg} / \mathrm{m}^{3}$, respectively.

A rise in the emission source height involves a decrease in the range of a zone with a given concentration level. For each concentration level there is such a height of the emission source that will make it impossible for it to rise. In other words, an increase in the height of the stack through which flue gases are carried out after the carbon dioxide capture process causes greater dispersion of the gas and a substantial reduction in the monoethanolamine concentration.

Fig. 6 presents changes in the MEA concentration depending on the distance from the emission source. Individual curves in the figure correspond to different heights of the emission source. The wind speed assumed for the calculations is $1 \mathrm{~m} / \mathrm{s}$.

For the assumed data, the stack height exceeding $30 \mathrm{~m}$ should keep MEA concentrations in air below $0.5 \mathrm{mg} / \mathrm{m}^{3}$.

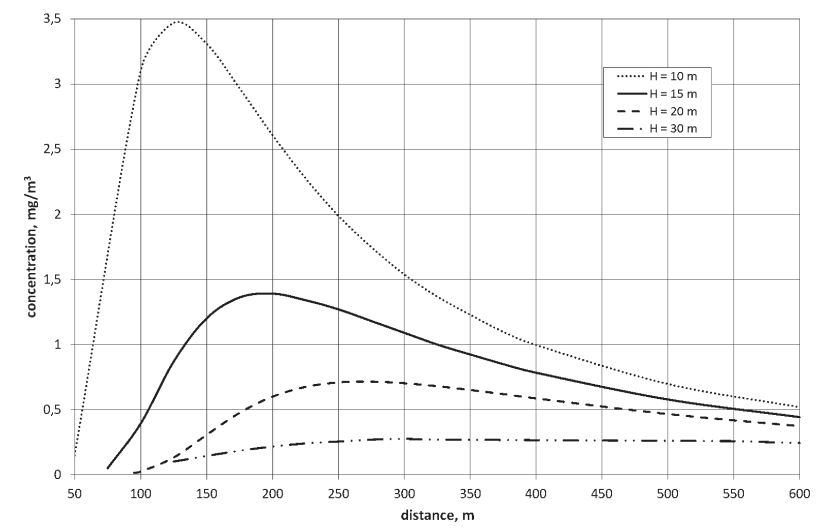

Fig. 6. Concentration depending on distance from the emission source.

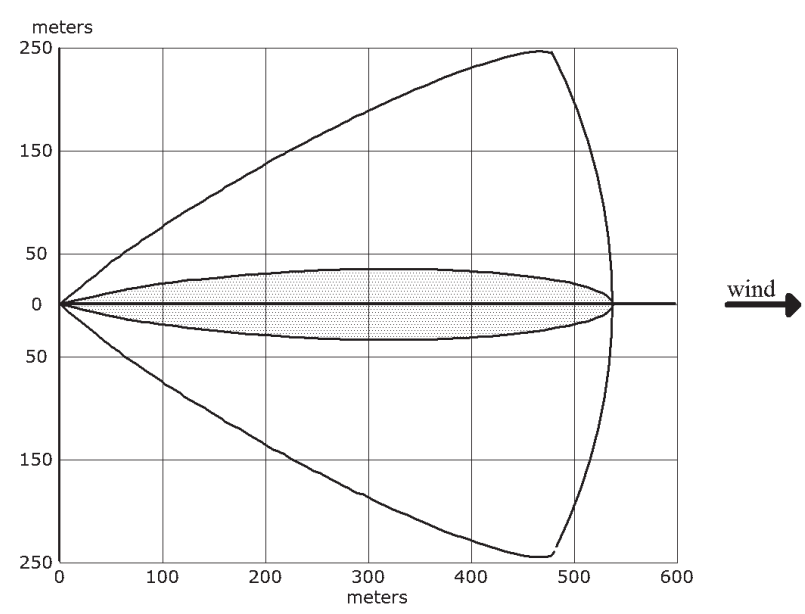

Fig. 7. Range of an NDMA cloud with a concentration higher than $10 \mu \mathrm{g} / \mathrm{m}^{3}$ (wind speed: $2 \mathrm{~m} / \mathrm{s}$ ).

\section{Spread of Compounds Formed due to Amine Decomposition}

The amines released in the absorption process accompanying carbon dioxide capture may react with atmospheric oxidants. This may lead to the formation of compounds posing hazards to humans, such as nitrosamines, nitramines, or acetamide [8].

The group of produced nitrosamines includes, e.g., NDMA (N-Nitrosodimethylamine). For the assumed 900 MW power unit, the mass flow of carbon dioxide captured in the amine installation is $157.43 \mathrm{~kg} \mathrm{CO}_{2} / \mathrm{s}$ [2]. Assuming that the installation operates for about $4,000 \mathrm{~h}$, annual $\mathrm{CO}_{2}$ emissions are at the level of 2 million tons. For this size of $\mathrm{CO}_{2}$ emissions and based on the data provided by [7], it is assumed that the NDMA emissions total $6.32 \cdot 10^{-2} \mathrm{~g} / \mathrm{s}$. For such emissions, Fig. 7 presents the range of the zone with a concentration higher than $10 \mu \mathrm{g} / \mathrm{m}^{3}$, which is considered to be harmful.

The NDMA formed due to amine degradation creates a hazardous concentration zone covering an area with a radius of more than $500 \mathrm{~m}$. The impact of the wind speed

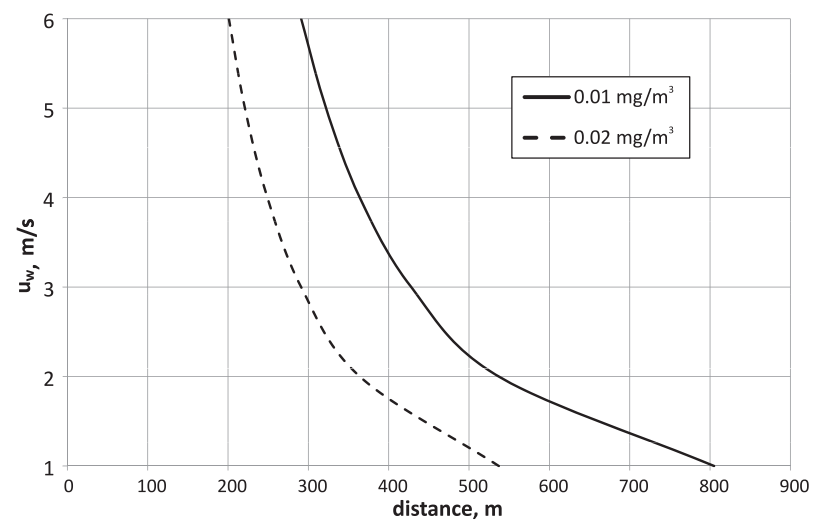

Fig. 8. Impact of wind speed on the range of a cloud with NDMA concentration of 0.01 and $0.02 \mathrm{mg} / \mathrm{m}^{3}$. 


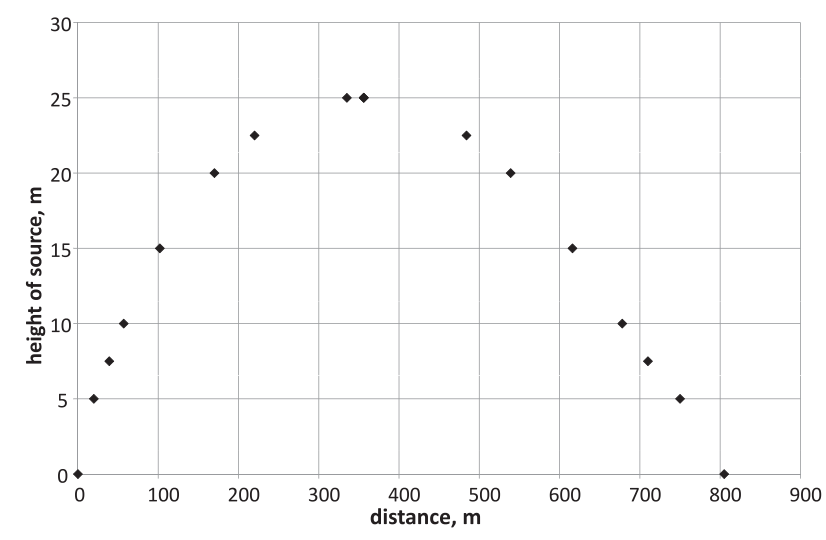

Fig. 9. Range of the zone with the NDMAconcentration of $10 \mu \mathrm{g} / \mathrm{m}^{3}$ at a variable height of the emission source.

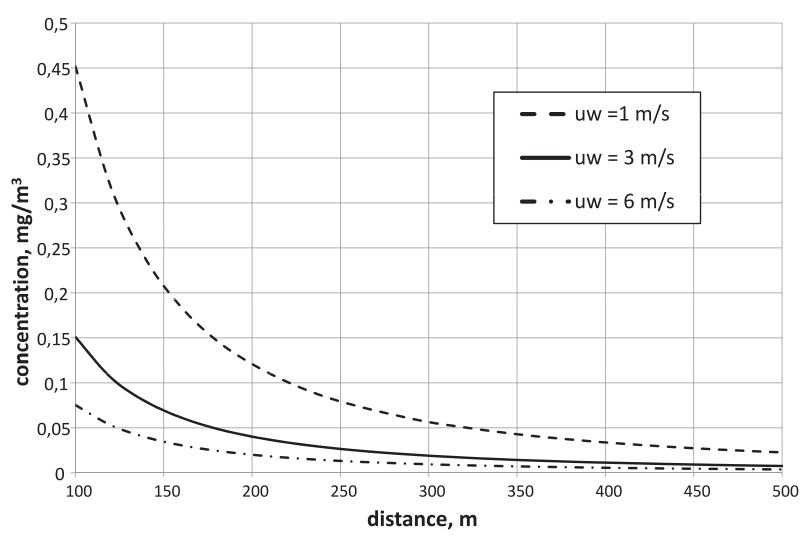

Fig. 10. Changes in the NDMA concentration depending on the distance from the emission source.

on the range of such a nitrosamine cloud is presented in Fig. 8.

The next figure (Fig. 9) presents changes in the range of the zone with an NDMA concentration equal to or higher than $10 \mu \mathrm{g} / \mathrm{m}^{3}$, depending on the emission source height. The wind speed assumed in the calculations is $1 \mathrm{~m} / \mathrm{s}$ and the emissions amount to $6.32 \cdot 10^{-2} \mathrm{~g} / \mathrm{s}$. Analysing

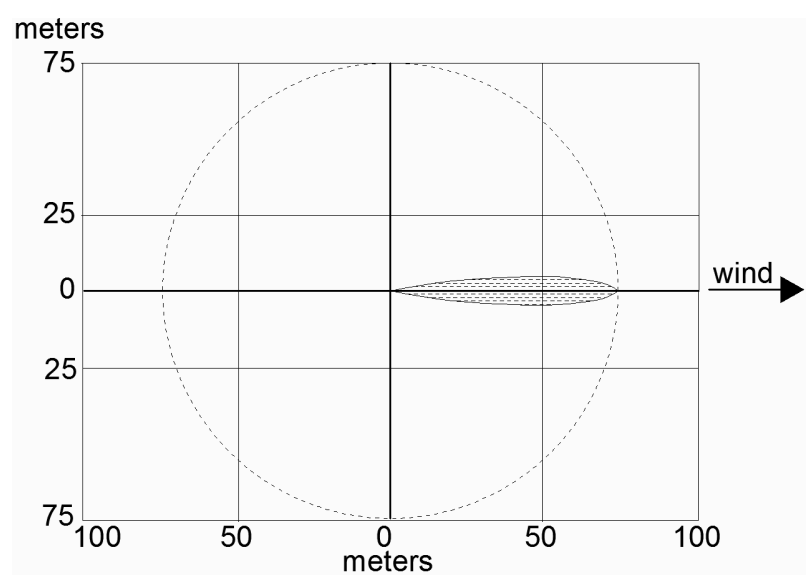

Fig. 11. Zone with an $18 \mathrm{mg} / \mathrm{m}^{3}$ concentration of formamide.

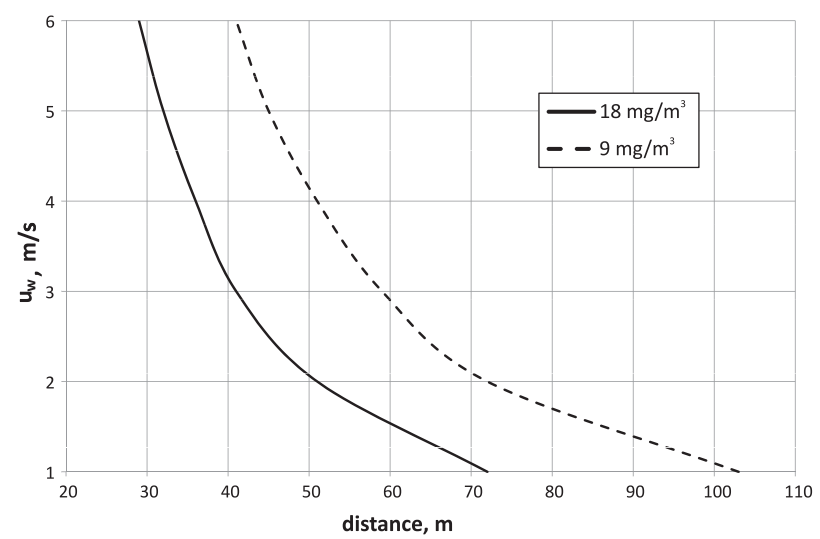

Fig. 12. Impact of wind speed on the range of a cloud with a formamide concentration of 9 and $18 \mathrm{mg} / \mathrm{m}^{3}$.

the chart, it can be seen that if the stack is higher than $25 \mathrm{~m}$, the cloud with the NDMA concentration posing a hazard to humans will not be formed. If the stack is $10 \mathrm{~m}$ high, the zone with the NDMA concentration of $10 \mu \mathrm{g} / \mathrm{m}^{3}$ will be 620 long and will cover the area located at a distance of from 57 to $678 \mathrm{~m}$ away from the emission source, and if the source height is $20 \mathrm{~m}$, the hazardous concentration zone will extend over a distance from 170 to $539 \mathrm{~m}$.

Changes in the NDMA nitrosamine concentration depending on the distance from the emission source for different wind speed values are presented in Fig. 10. Regardless of wind speed, at a distance exceeding $400 \mathrm{~m}$ no hazardous concentration should occur.

Another dangerous substance that may be formed due to amine emissions after the absorption-based carbon dioxide capture process is formamide. Fig. 11 presents the range of a zone with a permissible concentration of the substance higher than $18 \mathrm{mg} / \mathrm{m}^{3}$, assuming emissions at the level of $1.35 \cdot 10^{-3} \mathrm{~kg} / \mathrm{s}$ [8]. In the calculations, the wind speed and the atmospheric stability class are assumed at $1 \mathrm{~m} / \mathrm{s}$ and $\mathrm{D}$, respectively. The zone of the formamide concentration exceeding $18 \mathrm{mg} / \mathrm{m}^{3}$ will cover an area with a radius of about $72 \mathrm{~m}$.

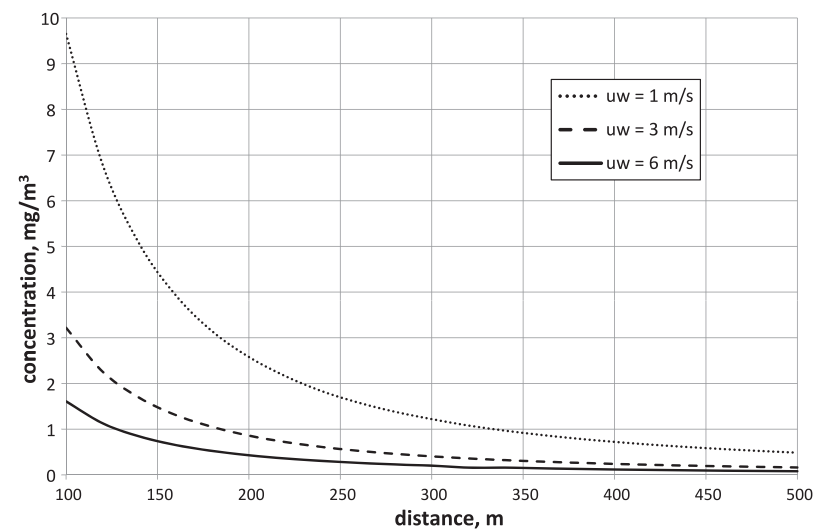

Fig. 13. Changes in the formamide concentration depending on distance from the emission source. 
A change in wind speed affects the range of a cloud with a given concentration of formamide, which is illustrated in Fig. 12.

Changes in the formamide concentration depending on the distance from the emission source are shown in Fig. 13.

At a distance of $100 \mathrm{~m}$ from the emission source the formamide concentration varies in the range $1.61-9.65 \mathrm{mg} / \mathrm{m}^{3}$ depending on wind speed. If the distance from the emission source is doubled, the formamide concentration drops to values between 2.58 and $0.43 \mathrm{mg} / \mathrm{m}^{3}$, depending on wind speed. If the distance is four times bigger, the concentration drops to values between about 0.72 and $0.22 \mathrm{mg} / \mathrm{m}^{3}$.

\section{Summary and Conclusions}

The results of the analyses indicate that if an aminebased carbon dioxide capture installation is used in power plants, compounds posing hazards to human health and ecosystems in general may be formed. The level of their emissions depends on installation size and capture capacity, but also on meteorological conditions. The zones with an increased concentration of monoethanolamine, for example, may reach a range of about $300 \mathrm{~m}$ from the emission source and they are reduced if there is a rise in wind speed. The size of the increased concentration zone is also affected by the emission source height. For example, in the case of compounds of nitrosamines their zone of concentrations higher than $10 \mu \mathrm{g} / \mathrm{m}^{3}$ will be about $800 \mathrm{~m}$ at small wind speed values. As the stack height gets bigger, the hazardous zone will become smaller, and at a certain height of the emission source, no zones with the hazardous substance will arise.

The presented results of estimated ranges of zones with an increased concentration of compounds formed in the amine-based absorption process indicate that such an analysis has to be conducted before a decision is made about the location of a $\mathrm{CO}_{2}$ capture installation, and that these factors also need to be taken into account at the stage of working out the installation's technical parameters.

\section{Acknowledgements}

The results presented in this paper were obtained from research co-financed by the National Center
Research and Development in the framework of Contract SP/E/1/67484/10 - Strategic Research Programme - Advanced technologies for energy generation: Development of a technology for highly efficient zeroemission coal-fired power units integrated with $\mathrm{CO}_{2}$ capture.

\section{References}

1. RAO A.B., RUBIN E.S. A Technical, Economic, and Environmental Assessment of Amine-Based $\mathrm{CO}_{2}$ Capture Technology for Power Plant Greenhouse Gas Control, Environmental Science \& Technology, 36, 4467, 2002.

2. BOCHON K., CHMIELNIAK T. Energy and economic analysis of the carbon dioxide capture installation with the use of monoethanolamine and ammonia, Archives of Thermodynamics, 36, 133, 2015.

3. WANG M., LAWAL A., STEPHENSON P., SIDDERS J., RAMSHAW C. Post-combustion $\mathrm{CO}_{2}$ capture with chemical absorption: A state-of-the-art review, 89 (3), 1609, 2011.

4. PEDERSEN S., SJØVOLL M., FOSTÅS B.F. Flue gas degradation of amines, IEA GHG Workshop, 2010.

5. GASCO AND GASSNOVA, Kårstø integration prefeasibility study, $\mathbf{2 0 1 0}$.

6. LIGOCKA D. 2-Aminoetanol Documentation of the limit of occupational exposure, Podstawy i Metody Oceny Środowiska Pracy, 4 (54), 97, 2007 [In Polish].

7. ZHANG Y., XU J., Zhang Y., ZHANG J., LI Q. Health risk analysisi of nitrosamine emissions from $\mathrm{CO}_{2}$ capture with monoethanolamine in coal-fired power plants, International Journal of Greenhouse Gas Control, 20, 37, 2014.

8. KARL M., WRIGHT R.F., BERGLEN T.F., DENBY B. Worst case scenario study to assess the environmental impact of amine emissions from $\mathrm{CO}_{2}$ capture plant, International Journal of Greenhouse Gas Control, 5, 439, 2011.

9. KARL M., SVENDBY T., WALKER S.-E., VELKEN A.S., CASTELL N., SOLBERG S.: Modelling atmospheric oxidation of 2-aminoetanol (MEA) emitted from postcombustion capture using WRF-Chem, Science of the Total Environment, 527-528, 185, 2015.

10. VELTMAN K., SINGH B., HERTWICH E.G. Human and environmental impact assessment of postcombustion $\mathrm{CO}_{2}$ capture focusing on emissions from amine-based scrubbing solvents to air, Enviromental Science technology, 44 (4), 1496, 2010.

11. LÅG M., LINDEMAN B., INSTANES C., BRUNBORG G., SCHWARZE P. Health effects of amines and derivatives associated with $\mathrm{CO}_{2}$ capture, The Norwegian Institute of Public Health, 2011.

12. ALOHA 5.4.4. Software, United States Environmental Protection, 2013. 